\title{
Meningkatkan Kemampuan Siswa dalam Menggunakan Bahasa Indonesia Dengan Menggunakan Metode Drill di kelas 2 Min 1 Indragiri Hilir
}

\author{
Normah $^{1}$ \\ ${ }^{1}$ Guru Kelas, Madrasah Ibtidaiyah Negeri 1 Tembilahan, Tembilahan Riau, Indonesia \\ *Corresponding author: normah@gmail.com
}

\begin{abstract}
Abstrak
Tujuan dari penelitian ini adalah untuk mengetahui apakah metode Drill dapat meningkatkan kemampuan siswa untuk menggunakan bahasa Indonesia di Kelas 2 MIN 1 Tembilahan. Jenis penelitian ini adalah Penelitian Tindakan Kelas. Responden dalam penelitian ini adalah siswa kelas 2 MIN Tembilahan. Mereka berjumlah 30 orang. Kelas ini dipilih sebagai tempat penelitian karena peneliti sebagai guru dikelas tersebut menemukan bahwa rendahnya kemampuan siswa dalam menggunakan Bahasa Indonesia. Untuk mencapai tujuan ini, 2 siklus penelitian tindakan kelas telah dilaksanakan. Setiap siklus terdiri dari 4 pertemuan. 3 pertemuan adalah pengajaran dengan menggunakan latihan dan satu lagi untuk ujian. Sebanyak. Metode yang digunakan untuk memperoleh data adalah observasi (untuk melihat kegiatan siswa dan guru selama pelaksanaan latihan), dan tes (untuk mengamati kemampuan siswa untuk berbicara bahasa Indonesia). Setelah menyelesaikan 2 siklus, peneliti menemukan bahwa metode Drill dapat Meningkatkan kemampuan siswa menggunakan bahasa Indonesia. Dengan demikian dapat peneliti simpulkan bahwa metode drill dapat membantu siswa dalam meningkatkan kemampuan mereka dalam berbahasa Indonesia
\end{abstract}

Kata Kunci: Indonesia, Metode Drill, Meningkatkan

\section{PENDAHULUAN}

Dalam pembelajaran Bahasa Indonesia, siswa kelas 2 MIN 1 Indragiri Hilir masih mengalami kesulitan. Mereka masih kesulitan dalam mengekspresikan Bahasa Indonesia sederhana dengan baik dan benar. Mereka cendrung mencampurkan Bahasa Indonesia dengan Bahasa sehari-hari mereka, yakni Bahasa Banjar. Karena di Tembilahan menggunakan Bahasa Banjar dalam pergaulan sehari-hari. Selain itu, mereka juga belum mampu meletakkan pertanyaan dengan tepat dalam Bahasa Indonesia. Mereka juga kurang antusias 


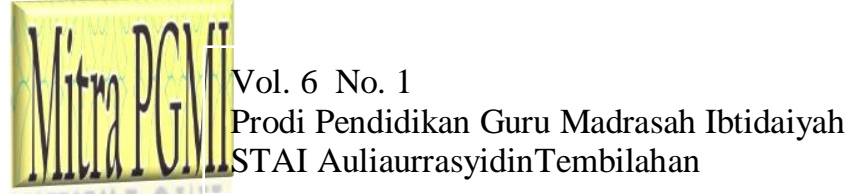

dalam proses pembelajaran. Mereka hanya mendengarkan guru dan enggan jika guru menunjuk mereka untuk mempraktekkan pelajaran kedepan kelas, sehingga hal tersebut berdampak pada kemampuan siswa yang masih rendah, yakni nilai mereka yang masih dibawah KKM (63). Yang mana KKM untuk mata pelajaran Bahasa Indonesia adalah 70.

Setelah peneliti melakukan analisa, salah satu penyebab masalah yang timbul pada siswa diatas adalah metode yang digunakan dalam pembelajaran masih belum mampu mendorong mereka untuk menjadi antusias dalam belajar. Metode yang dipilih dan diaplikasikan di kelas sangat berperan penting dalam perkembangan pembelajaran siswa. Dengan kata lain, kemampuan siswa dapat meningkat jika menggunakan metode yang lebih baik. Oleh karena itu, untuk mengatasi permasalahan yang terjadi maka penelitiberusaha untuk memperbaiki metode pembelajaran yang memungkinkan kemampuan Bahasa Indonesia siswa dapat meningkat, sehingga tercapailah tujuan pembelajaran. Dengan berlandaskan permasalahan diatas, sehingga peneliti tertarik untuk melakukan penelitian dengan menempatkan metode pembelajaran yang sesuai yaitu dengan menerapkan metode drill.

Oleh karena itu, peneliti tertarik menggunakan metode drill dalam pembelajaran Bahasa Indonesia dengan tujuan meningkatkan kemampuan Bahasa Indonesia siswa kelas 2 MIN Tembilahan. Maka Peneliti merancang penelitian ini dengan judul "Meningkatkan Kemampuan Bahasa Indonesia Siswa dengan Menggunakan Metode Drill Dikelas 2 di MIN 1 Indragiri Hilir”.

\section{METODE PENELITIAN}

Jenis penelitian ini adalah Penelitian Tindakan Kelas. Responden dalam penelitian ini adalah siswa kelas 2 MIN Tembilahan. Mereka berjumlah 30 orang. Kelas ini dipilih sebagai tempat penelitian karena peneliti sebagai guru dikelas tersebut menemukan bahwa rendahnya kemampuan siswa dalam menggunakan Bahasa Indonesia. Olehkarena itu, metode drill dipilih sebagai solusi terhadap masalah yang dihadapi. Untuk mengumpulkan data, peneliti bersama kolaborator telah mempersiapkan observasi. Observasi ini terdiri dari ceklis kegiatan guru dan siswa serta catatan lapangan. Selain itu, tes juga digunakan untuk mengetahui 


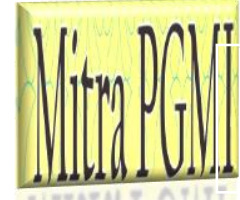

kemampuan siswa dalam menggunakan Bahasa Indonesia pada setiap akhir siklus. Untuk menganalisa data yang telah diperoleh, peneliti menggunakan qualitative analisis untuk observasi dan quantitative analisis untuk hasil tes

\section{HASIL DAN PEMBAHASAN}

Setelah penelitian selama dua siklus dilakukan, peneliti menemukan bahwa kemampuan siswa kelas 2 MIN 1 Indragiri Hilir dalam menggunakan Bahasa Indonesia setelah diajar menggunakan metode drill meningkat cukup baik pada setiap siklus, meskipun nilai akhir mereka pada siklus 2 hanya meningkat 1 poin saja dari nilai KKM. Namun, jika dilihat dari aktifitas mereka melalui observasi, terlihat cukup meningkat dengan baik. Meskipun demikian terdapat peningkatan pada nilai siswa setiap siklus. Pada siklus pertama nilai rata-rata mereka adalah 67.4. Ini berarti bahwa ada peningkatan nilai mereka sebanyak 4 poin dibanding dengan nilai awal mereka sebelum adanya metode drill, yakni 63. Selain itu, pada siklus 2, nilai mereka meningkat kembali menjadi 71.3. Ini berarti ada peningkatan kembali sebanyaj 4 poin dari pada siklus pertama. Dengan demikian dapat dijelaskan bahwa metode drill dapat membantu siswa dalam meningkatkan kemampuan mereka dalam berbahasa Indonesia

Bahasa Indonesia mempunyai kedudukan yang sangat penting, seperti tercantum pada ikrar ketiga Sumpah Pemuda 1928 yang berbunyi Kami putra dan putri Indonesia menjunjung bahasa persatuan, bahasa Indonesia. Ini berarti bahwa bahasa Indonesia berkedudukan sebagai bahasa nasional; kedudukannya berada diatas bahasa-bahasa daerah. Selain itu, didalamUndang-Undang Dasar 1945 tercantum pasal khusus (Bab XV, pasal 36) mengenai kedudukan bahasa Indonesia yang menyatakan bahwa bahasa Negara ialah bahasa Indonesia. Dengan kata lain, ada dua macam kedudukan bahasa Indonesia. Pertama, bahasa Indonesia berkedudukan sebagai bahasa nasional sesuai dengan Sumpah Pemuda 1928; kedua, bahasa Indonesia berkedudukan sebagai bahasa Negara sesuai dengan Undang-Undang Dasar 1945. ${ }^{1}$

1 Zaenal Arifin \&AmranTasai. Cermat Berbahasa Indonesia (Jakarta: AkademikaPressindo. 2009), hlm. 12. 
Pemakaian bahasa Indonesia dalam dunia pendidikan diantaranya; ${ }^{2}$

1. Bahasa Indonesia digunakan sebagai bahasa pengantar dalam proses pembelajaran sejak TK sampai perguruan tinggi.

2. Bahasa Indonesia digunakan untuk penulisan buku-buku pelajaran (buku teks) penerjemahan buku-buku refrensi dalam berbagai bidang ilmu, penyajian materi disemua lembaga pendidikan untuk masyarakat umum.

3. Bahasa Indonesia digunakan untuk menyampaikan laporan hasil belajar peserta didik baik dalam buku laporan pendidikan (raport) maupun dalam bentuk laporan hasil belajar yang baik.

4. Bahasa Indonesia digunakan untuk pengembangan bahan ajar, strategi pembelajaran, evaluasi pembelajaran, pengelolaan sumber belajar, pembuatan dan penggunaan media pembelajaran.

Dapat disimpulkan bahwa bahasa Indonesia merupakan bahasa yang memiliki peran penting bagi bangsa Indonesia, selain sebagai alat komunikasi lisan, juga digunakan untuk komunikasi secarea tertulis, bahasa Indonesia merupakan bahasa pengantar dari tingkat TK hingga perguruan Tinggi. Sehingga menjadi salah satu mata pelajaran wajib hamper seluruh lembaga pendidikan yang ada di Indonesia.

Berikut ini aspek-aspek yang dinilai dalam meningkatkan kemampuan berbahasa Indonesia antara lain;

1. Diksi atau pilihan kata (ketepatan dan kesesuaiannya)

Diksi adalah pilihan kata. Maksdunya, kita memilih kata yang tepat untuk menyatakan sesuatu. Pilihan kata merupakan satu unsur yang sangat penting, baik dalam dunia karang-mengarang maupun dalam dunia tutur setiap hari. Dalam memilih kata yang setepat-tepatnya untuk menyatakan suatu maksud, kita tidak dapat lari dari kamus. Kamus memberikan suatu ketetapan kepada kita tentang pemakaian kata-kata. Dalam hal ini, makna kata yang tepatlah yang diperlukan. ${ }^{3}$

Keraf (2002) menjelaskan bahwa pilihan kata tidak hanya mempersoalkan ketepatan pemakaian kata, tetapi juga mempersoalkan apakah kata yang dipilih itu

${ }^{2}$ I Nyoman Juniardianta. Peningkatan Kemampuan Berbahasa Indonesia Melalui Metode Drama pada Siswa Kelas VII C SMP Dharma Raja (Universitas Warmadewa; Jurnal Ilmu Bahasa. 2017), hlm. 50.

3 Zaenal Arifin \&AmranTasai, Op. Cit, hlm.28 


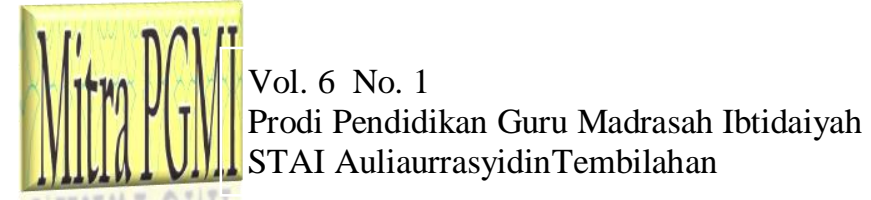

dapat juga diterima atau tidak merusak suasana yang ada. Sebuah kata yang tepat untuk menyatakan suatu maksud tertentu, belum tentu dapat diterima oleh orang yang diajak bicara. Masyarakat yang diikat oleh berbagai norma, menghendaki pula agar setiap kata yang dipergunakan harus serasi dengan norma-norma masyarakat, harus sesuai dengan situasi yang dihadapi. ${ }^{4}$

Dapat disimpulkan bahwa kata yang tepat akan membantu seseorang mengungkapkan dengan tepat apa yang ingin disampaikannya, baik lisan maupun tulisan. Disamping itu, pemilihan kata itu harus sesuai pula dengan situasi dan tempat penggunaan kata-kata itu. Kata-kata yang tepat digunakan untuk mengungkapkan suatu ide atau gagasan, tetapi meliputi juga fraselogi, gaya bahasa,dan ungkapan.

\section{Tata Bahasa}

Tata bahasa adalah cabang ilmu pengetahuan yang mempelajari kaidahkaidah yang mengatur penggunaan bahasa.Tata bahasa juga merupakan suatu himpunan dari patokan-patokan dalam struktur bahasa. Struktur bahasa itu meliputi tata bunyi, tata bentuk, tata kata, tata kalimat dan tata makna. dengan kata lain, tata bahasa meliputi bidang-bidang fonologi, morfologi, dan sintaksis. ${ }^{5}$

Dimensi tata bahasa yang dikemukakan Murcia\&Freeman (1999) adalah tata bahasa bukan semata sekumpulan bentuk tetapi merupakan keterlibatan tiga dimensi yang diacu oleh linguistik, yaitu (morfologi) sintaksis, semantik, dan pragmatik. Bahwa, struktur tatabahasa tidak hanya memiliki bentuk morfosintaksis, tetapi bentuk itu juga digunakan untuk mengungkapkan makna (semantik) di dalam konteks yang sesuai (pragmatik). Keterlibatan dimensidimensi tatabahasa itu digambarkan sebagai dimensi bentuk, makna, dan dimensi penggunaan. Dimensi bentuk adalah bagaimana bentuk bahasanya (ketepatan/accuracy). Dimensi makna adalah apa maknanya (kebermaknaan /meaningfulness). Dimensi penggunaan adalah kapan/mengapa digunakan (kesesuaian/appropriateness). Dalam rangka mengungkapkan atau memahami

${ }^{4}$ Chori Latifah, dkk. Penggunaan Diksi dalam Karangan Berita Siswa Sekolah Menengah Pertama (Universitas Sebelas Maret; Jurnal Penelitian Bahasa, Sastra Indonesia dan Pengajarannya. 2016), hlm. 84.

\footnotetext{
${ }^{5}$ I Nyoman Juniardianta, Loc.Cit, hlm.192
} 


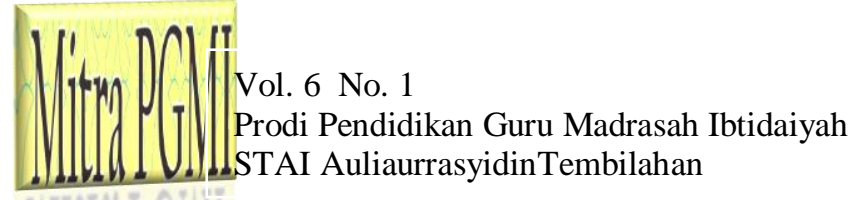

bahasa, orang akan membentuk sistem yang menghubungkan bahasa yang didengarnya dengan maknanya. Secara tradisional itu disebut sebagai gramatika bahasa. ${ }^{6}$

Kaidah gramatikal atau tata bahasa merupakan inti kesimpulan bagaimana orang berpikir yaitu bagaimana perilaku manusia dalam pengungkapan berbahasa. Kaidah-kaidah yang telah tersedia itu memberikan kemungkinan kepada bahasawan untuk membentuk kata. Jadi, kaidah bahasa atau tata bahasa adalah fakta psikolologis, ada pada setiap benak manusia dan ada penguasaan atas kaidah itu, untuk digunakan secara fungsional. ${ }^{7}$

Metode drill merupakan metode mengajar dengan memberikan latihanlatihan kepada siswa untuk memperoleh suatu keterampilan. Latihan ini merupakan kegiatan yang selalu diulang-ulang seperti melatih keterampilan motoris: menggunakan alat-alat music, olaharaga, kesenian, kecakapan mental seperti menghafal, mengali, menjumlah dan sebagainya. ${ }^{8}$

Metode Drill adalah suatu cara mengajar dimana siswa melaksanakan kegiatan-kegiatan latihan, agar siswa memiliki ketangkasan atau keterampilan yang lebih tinggi dari apa yang dipelajari. Menurut Nana Sudjana, metode Drill adalah satu kegiatan melakukan hal yang sama, berulang-ulang secara sungguhsungguh dengan tujuan untuk memperkuat suatu asosiasi atau menyempurnakan suatu keterampilan agar menjadi bersifat permanen. Ciri yang khas dari metode ini adalah kegiatan berupa pengulangan yang berkali-kali dari suatu hal yang sama. $^{9}$

Dalam melaksanakan pembelajaran dengan metode Drill, guru harus mempertimbangkan kesiapan dari guru tersebut, siswa dan segala fasilitas yang

${ }^{6}$ Sintowati Rini Utami. Pembelajaran Aspek Tata Bahasa Dalam Buku Pelajaran Bahasa Indonesia (Universitas Negeri Jakarta; Jurnal Pendidikan Bahasa, Sastra Indonesia. 2017), hlm. 192.

${ }^{7}$ Ibid

${ }^{8}$ Buchari Alma. Guru Profesional Menguasai Metode dasn Terampil Mengajar (Bandung; Alfabeta, 2012), hlm. 75.

${ }^{9}$ L. Damayanthi https:// www. academia. edu/ 9208697/ A_METODE_DRILL_ Langkah-langkah_Penggunaan_Metode_Drill 
mendukung. Langkah-langkah dalam penggunaan metode Drill ini terdiri dari beberapa tahap yaitu sebagai berikut: ${ }^{10}$

1. Tahap Persiapan

Pada tahap ini, ada beberapa hal yang dilakukan, antara lain:

1) Rumuskan tujuan yang harus dicapai oleh siswa

2) Tentukan dengan jelas keterampilan secara spesifik dan berurutan

3) Tentukan rangkaian gerakan atau langkah yang harus dikerjakan untuk menghindari kesalahan

4) Lakukan kegiatan pradrill sebelum menerapkan metode ini secara penuh

2. Tahap Pelaksanaan

1) Langkah Pembukaan

Dalam langkah pembukaan, beberapa hal yang perlu dilaksanakan oleh guru diantaranya mengemukakan tujuan yang harus dicapai, bentuk-bentuk latihan yang akan dilakukan.

2) Langkah Pelaksanaan

a) Memulai latihan dengan hal-hal yang sederhana dulu

b) Ciptakan suasana yang menyenangkan

c) Yakinkan bahwa semua siswa tertarik untuk ikut

d) Berikan kesempatan Ikepada siswa untuk terus berlatih

3) Langkah Mengakhiri

Apabila latihan sudah selesai, maka guru harus terus memberikan motivasi untuk siswa terus melakukan latihan secara berkesinambungan sehingga latihan yang diberikan dapat semakin melekat, terampil dan terbiasa. 
3. Penutup

1) Melaksanakan perbaikan terhadap kesalahan-kesalahan yang dilaksanakan oleh siswa.

2) Memberikan latihan penenangan.

Imansjah Alipandi menjelaskan mengenai kelebihan dalam metodedrill adalah sebagai berikut: ${ }^{11}$

1. Dengan metode ini dalam waktu yang relatif singkat anak-anak segeramemperoleh penguasaan dan keterampilan yang diharapkan.

2. Para siswa memiliki sejumlah besar pengetahuan siap.

3. Para siswa terlatih belajar secara rutin dan disiplin.

4. Membiasakan siswa saling bekerjasama, dan memberikan kepadamereka untuk mengembangkan sikap musyawarah dan bertanggungjawab.

5. Guru tidak perlu mengawasi masing-masing siswa secara individualcukup dengan memperhatikan kelompok saja dan ketua kelompoknya.

Kesadaran akan adanya kelompok yang menimbulkan rasa kompetitifyang sehat, sehingga membangkitkan kemauan belajar yang sungguhsungguh.

\section{KESIMPULAN DAN SARAN}

Penelitian ini dilakukan untuk menemukan jawaban atas pertanyaan penelitian yakni "apakah metode drill dapat meningkatkan kemampuan siswa kelas 2 MIN 1 Indragiri Hilir dalam menggunakan Basaha Indonesia?”. Setelah menganalisa data baik secara kualitatif maupun kuantitatif, dapat disimpulkan bahwa metode drill dapat meningkatkan kemampuan siswa dalam menggunakan Bahasa Indonesia, baik dalam keaktifan mereka dalam belajar, motivasi mereka dan juga nilai mereka. Yang mana pada saat sebelum metode drill diaplikasikan,

${ }^{11}$ Mazlina Tri Utary. Pengaruh Penggunaan Metode Drill terhadap Hasil Belajar Siswa pada Mata Pelajaran Bahasa Indonesia dikelas IV MIN Sei Agul Kec. Medan Denai. (Medan: Universitas Islam Negeri. 2018), hlm.32. 


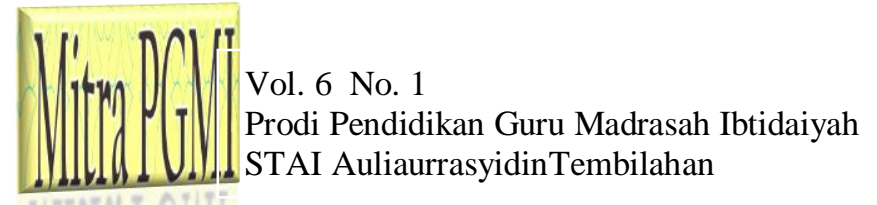

siswa kurang aktif dikelas dan kurang termotivasi ketika belajar Bahasa Indonesia. Selain itu, nilai mereka juga sangat jauh dibawah KKM, yakni 63. Namun setelah aplikasi metode drill, siswa sangat antusias dan termotivasi dalam mempraktekkan cara menggunakan Bahasa Indonesia yang baik dengan kalimat sederhana dan nilai mereka berangsur naik dari 63 menjadi 67.4 dan kemudian 71.3.

Berdasarkan temuan di atas, peneliti menyarankan kepada guru-guru, khususnya di MIN 1 Indragiri Hilir untuk dapat mencoba metode drill ini kepada mata pelajaran lain, karena metode drill ini terbukti mampu meningkatkan kemampuan siswa dalam belajar Bahasa Indonesia. Maka dari itu, sangat memungkinkan metode ini juga dapat diaplikasikan pada mata pelajaran yang lain.

\section{DAFTAR PUSTAKA}

Alma, Buchari. 2012. Guru Profesional Menguasai Metode dasn Terampil Mengajar, Bandung; Alfabeta.

Arikunto, Suharsimi. 2006. Prosedur Penelitian, Jakarta: PT Rineka Cipta.

Arifin, Zaenal \& Amran Tasai. 2009. Cermat Berbahasa Indonesia, Jakarta: Akademika Pressindo.

Djamarah, Syaiful Bahri \& Azwan Zain. 2010. Strategi Belajar Mengajar. Jakarta: Rineka Cipta.

Juniardianta, I Nyoman. 2017. Peningkatan Kemampuan Berbahasa Indonesia Melalui Metode Drama pada Siswa Kelas VII C SMP Dharma Raja Universitas Warmadewa. Jurnal Ilmu Bahasa.

Latifah, Chori, dkk. 2016. Penggunaan Diksi dalam Karangan Berita Siswa Sekolah Menengah Pertama. Jurnal Penelitian Bahasa

L. Damayanthi https:// www. academia. edu/ 9208697/ A_METODE_DRILL_ Langkah-langkah_Penggunaan_Metode_Drill

Riduan, 2013, Skala Pengukuran Variabel-variabel Penelitian. Bandung. Alfabeta.

Sanjaya, Wina. 2006. Strategi Pembelajaran Berorientasi Standar Proses Pendidkan, Jakarta; Kencana

Sudjana. 2005. MetodaStatitistika, Bandung: Tarsito

Utami, Sintowati Rini. 2017. Pembelajaran Aspek Tata Bahasa Dalam Buku Pelajaran Bahasa Indonesia. Universitas Negeri Jakarta. Jurnal Pendidikan Bahasa. Jakarta. 
Utary. Mazlina Tri. 2018. Pengaruh Penggunaan Metode Drill terhadap Hasil Belajar Siswa pada Mata Pelajaran Bahasa Indonesia dikelas IV MIN Sei Agul Kec. Medan Denai. Medan. Skripsi. Universitas Islam Negeri. Medan.

Wati, Novera Kusuma. 2017. Penerapan Metode Drill dalam Pembelajaran Bahasa Indonesia Materi Pantun Anak pada Siswa Kelas IV.A MIN Bireueun Tahun Pelajaran 2016/2017. Jurnal Media Inovasi. Aceh 